\title{
UNDERWATER WELDING AND CUTTING IN CIS COUNTRIES
}

\author{
V.Ya. KONONENKO \\ E.O. Paton Electric Welding Institute, NASU \\ 11 Bozhenko Str., 03680, Kiev, Ukraine. E-mail: office@paton.kiev.ua
}

\begin{abstract}
At the present time there are two main types of welding works under water: hyperbaric dry welding and wet welding. Both methods are successfully applied at the territory of CIS countries for repair and construction of metal structures under water. Hyperbaric dry welding is the most demanded in cases of repair works at underwater gas pipelines passages across water barriers, because it provides high predicted level of mechanical properties of welded joints. Wet welding is demanded at construction and repair of hydrotechnical objects such as berths, basements of extracting platforms and also at lifting and emergency repair of ships and vessels. For its fulfillment the covered electrodes and mechanized welding process using self-shielding flux-cored wires are used. The mechanical properties of welded joints, which are provided by these technologies, are at the level of mechanical properties of joints produced in welding in air using electrodes of the type E42 and E46. However during realization of these technologies there is a possibility of defect formation caused by a sharp cooling of weld metal and human factor during work of a diver-welder under water. At the present time to perform underwater cutting the most challenging are the technologies of underwater electric-oxygen cutting and cutting using exothermal electrodes, which are produced both at the territory of CIS countries as well as beyond their borders. These technologies provide comparatively low level of productivity and necessity of additional mechanical treatment of the cutting zone in case of the further producing of welded joints. Using dry and wet welding at the territory of CIS countries a great volume of works was performed connected with repair of underwater pipelines, berth erections, lifting and repair of ships and vessels. The most significant work at the recent time was performed in construction of off-shore ice-resistant stationary platform «Prirazlomnaya». 9 Ref., 3 Tables.
\end{abstract}

$\boldsymbol{K} \boldsymbol{e} \boldsymbol{y} \boldsymbol{w} \boldsymbol{o r d} \boldsymbol{s}:$ dry underwater welding, wet welding, covered electrodes, flux-cored wires, mechanical properties of joints, performed works

At the present time there are two main types of performance of welding works under water [1]:

- hyperbaric dry welding, which is performed inside the dry inhabited chamber, mounted around the welded elements under pressure, the value of which depends on the depth [2];

- wet welding, which is performed under the conditions of direct contact with water under pressure, the value of which depends on the depth of performance of welding works.

Hyperbaric dry welding was applied for the first time by the company «Taylor Diving and Salvage» (USA) in 1967 [2]. The main purpose of this welding method consists in prevention of contact between arc burning zone and metal being welded with water, that offers essential advantages to produce the full-strength welded joint independently of outer conditions and depth. It should be noted that use of this technology as applied to the repair of tubular elements of stationary basements, hulls of ships, berths and other hydrotechnical objects with the developed surface is connected with great mate- rial costs. Dry welding also represents a significant inconvenience in inhabited chambers during repair of underwater pipeline passages across small water barriers. In this case it is impossible to use specialized deep-seated ships with the necessary equipment and hoisting mechanisms.

However, considering the high predictable level of quality of joints, produced using dry welding, recently the colleagues of the company «Podvodservis Ltd.» in Russia successively performed a whole number of works on repair of gas pipelines passages across small water barriers using specialized Zakharov caisson (SZC) [3, 4]. SZC is designed for its mounting to the defective area of the repaired pipeline of diameter from 325 to $1420 \mathrm{~mm}$ at the depths up to $60 \mathrm{~m}$. SZC represents a diving bell, made in the form of a metallic box opened from the bottom, the side surfaces of which are manufactured with the possibility of its mounting on the pipeline outer surface. The air-tightness of arrangement on the surface of main pipeline is provided by a rubber sealer positioned around the perimeter of box sides adjacent to the outer surface. The welding of pipe defect is performed in gas environment by a diver-welder with diving equipment, working inside the SCZ. The supply of air for breath- 
ing of a diver and discharge of exhaled air out of the caisson are performed through the special hose-cable without violations of required composition of gas mixture inside the caisson. Using this equipment the repair works of underwater gas pipeline at the passage across the Lena river at $10 \mathrm{~m}$ depth by the OJSC «Sakhatransneftegaz», gas pipeline (branching to Zarechie) of $530 \mathrm{~mm}$ diameter, across the $\mathrm{Ob}$ river at $8 \mathrm{~m}$ depth by the «Tyumentransgaz Ltd.» and also reserve line of $1220 \mathrm{~mm}$ diameter of the underwater passage of gas pipeline Yamburg-Yelets 2 were performed.

With the purpose of the further implementation of technology of welding in the specialized caisson under water, in particular, to provide a possibility not only to reweld certain defects of a pipe body, but also to create technology of repair of a pipeline using method of «coil cut-in», the designers of «Podvodservis» together with «Gazprom Transgaz Yugorsk Ltd.» developed, tested and commissioned the repair complex with a fit-on frame [4]. The design of caisson allows embracing all the surface of pipeline of $1220 \mathrm{~m}$ diameter and provides a possibility of simultaneous work of two divers-welders. The complex of technical facilities includes the equipment (welding and auxiliary) for cutting, alignment and welding of pipe body, the specialized caisson, designed for sealed positioning on the pipeline and also the fit-on frame, providing alignment of pipe areas during cutting. The complex has equipment for heat treatment and next ultrasonic flaw detection of welds. The work of the repair complex is based on the principle of dry hyperbaric welding in inert gases.

Welding inside the caisson at atmospheric pressure. This technological process is performed under dry conditions at atmospheric pressure. A chamber is put on the pipe, being repaired, and hermetically joined to it. The welder is working inside the chamber and after the performance of repair works it remains on the object. This technological process did not find a wide application in the world practice. The works in this working chamber are restricted by the depth of a basin, which amounts usually to $10-12 \mathrm{~m}$, however, on the Volga river in Russia the repair works at the depth of $30 \mathrm{~m}$ were performed using this technology.

Besides the repair of pipelines the dry welding at atmospheric pressure is applied for repair of berth erections. For this purpose the specialized caisson is manufactured, being opened from the side and top part. Sealing along the side surface is performed in places of chamber adjacent to the berth structure being repaired. As a rule, the length of a caisson is 5-6 m, the height is $3-4 \mathrm{~m}$. The caisson is moved during repair of berth structure. After its drying for repair the standard welding consumables, used for welding in air, are applied. Such caissons are used in Lithuania and Latvia. It is quite profitable to perform repair works as far as there is no need in lowering of a diver under water in welding of main number of defects. The repair of these metal structures at depth of more than $3 \mathrm{~m}$ is performed using covered electrodes designed for wet welding by the diving equipment.

Wet welding. In wet welding the welder and object, being welded, are located in the water environment. The process is performed without any additional fixtures and devices. Due to that, the welder has more freedom in movements, which makes the wet welding very efficient and economic method of welding under water, first of all, in restoration of metal structures with the developed surface at the depth of up to $20 \mathrm{~m}$ [3].

To perform such works the electrodes of foreign production are most often applied in CIS countries, however, in Ukraine and Russia the electrodes for wet underwater welding are also designed and produced under laboratory and industrial conditions. Mechanical properties of the joints, which are provided using these electrodes, are given in Table 1. It should be noted that the field of application of wet method of welding with covered electrodes is restricted due to low mechanical properties of joints, insufficient efficiency of the process and high requirements to the skill of diver-welder.

To increase the probability of producing joints with the predicted level of quality it is necessary to decrease the probability of cold cracks formation, which is achieved due to control of thermal cycle of welding [3]. It can be realized due to technological measures by adjustment of welding condition parameters, facilitating the decrease in cooling rate of welded joint and probability of formation of tempered structures and, as a result, of underbead cracks. It is possible to decrease the cooling rate of welded joint also by deposition of heat insulating layer on its surface.

The experience in manufacture and service of metal structures of pipe steels of increased strength shows that during selection of electrode consumables for its welding in the air it is necessary to try producing the weld metal with higher ductile properties, even if its strength is somewhat lower than the strength of base metal [3]. Ductile weld with the strength lower than that of base metal is a soft interlayer, which 
VIII INTERNATIONAL CONFERENCE «WELDING CONSUMABLES》

Table 1. Mechanical properties of joints produced using wet welding under water

\begin{tabular}{|c|c|c|c|c|c|}
\hline Grade of electrode & $\begin{array}{l}\text { Tensile strength } \sigma_{\mathrm{t}} \text {, } \\
\mathrm{MPa}\end{array}$ & Yield strength $\sigma_{y}, \mathrm{MPa}$ & Elongation $\delta_{5}, \%$ & $\begin{array}{l}\text { Impact toughness } \\
K C V_{-20}, \mathrm{~J} / \mathrm{cm}^{2}\end{array}$ & $\begin{array}{c}\alpha_{\text {bend }}, \text { deg, acc. to class } \\
\text { B of AWS D3.6M }\end{array}$ \\
\hline \multicolumn{6}{|c|}{ Covered electrodes } \\
\hline EPS-52 & $390-420$ & Not standardized & $6-20$ & $\mathrm{~N} / \mathrm{D}$ & Not standardized \\
\hline EPS-AN1 & $\geq 420$ & Same & $\geq 14$ & Same & Same \\
\hline E38-LKI-1P & 410 & $\gg$ & $\leq 8$ & $\gg$ & $\gg$ \\
\hline \multicolumn{6}{|c|}{ Self-shielding flux-cored wires } \\
\hline PPS-AN1 & $400-430$ & $300-320$ & $14-16$ & $\geq 10$ & 180 \\
\hline PPS-AN2 & $400-440$ & $300-340$ & $13-18$ & $\geq 25$ & 180 \\
\hline PPS-AN5 & $420-460$ & $320-360$ & $13-17$ & $\geq 25$ & 180 \\
\hline PPS-EK1 & $400-460$ & $300-360$ & $14-18$ & $\geq 25$ & 180 \\
\hline
\end{tabular}

during tension begins to deform earlier than yield strength of base metal is achieved, that results in contact strengthening of weld metal. A great number of works under water was performed using electrode consumables, providing a considerably lower level of weld metal strength than that of base metal. Some of these works were performed during welding of pipe steels, the carbon equivalent $\left(\mathrm{C}_{\mathrm{eq}}\right)$ of which amounted to $0.38-$ $0.40 \%$, and $\sigma_{t}=440-500 \mathrm{MPa}$ (Table 2). The same as in welding in the air the use of electrode consumables providing weld metal with the lower level of strength than that of base metal $\left(\sigma_{\mathrm{t}}=410-430 \mathrm{MPa}\right)$ allowed solving the problem of repair underwater welding. The weld metal of the lower strength began to deform plastically under the influence of working loads, which caused its contact strengthening. Here, the total level of strength of welded joints was sufficient to provide the reliable operation of underwater passages of gas pipelines.

The technology of mechanized wet underwater welding using self-shielding flux-cored wires, developed at the E.O. Paton Electric Welding Institute [5], is widely applied in the CIS countries since 1969. Technological process is universal and allows obtaining sufficiently high predicted level of mechanical properties of the joints in case of welding of low carbon and a number of low-alloy hull steels at all the spatial positions using fluxcored wires of ferrite class, if a user has certain skills (Table 3). Using this technology the efficiency of the process is considerably increased, which is $3-6$ times higher as compared to welding using covered electrodes. This aspect is extremely important during the work of a diver under water. To the disadvantages of the method of mechanized wet welding using self-shielding flux-cored wire, the same as in welding using covered electrode, the sharp cooling of metal of welded joint in water and its significant saturation with hy- drogen and oxygen can be referred [3]. It can lead to cold cracks formation in welded joints produced on some low-alloy pipe steels of increased strength with $\mathrm{C}_{\mathrm{eq}} \geq 0.39 \%$ using electrode consumables of ferrite class. Using this technological process a number of works on repair of underwater pipeline passages across the water basins [3,6] and other hydrotechnical objects was performed in the former USSR.

The most significant recent work using the technology of mechanized wet welding was performed in 2004-2005 during construction of the off-shore ice-resistant stationary platform (OIRSP) «Prirazlomnaya» [7-9] at the FSUE «P Sevmashpredpriyatie». The lower part of the OIRSP is the caisson, representing a welded structure of cold-resistant steels of the sizes $126 \times$ $\times 126 \times 24.3 \mathrm{~m}$ and mass of about 70,000 $\mathrm{t}$ and providing storage of 700,000 barrels of oil. It is not possible to assembly such a structure on the beds of the plant «Sevmashpredpriyatie». To join the sections (superblocks) the known technology of stage-by-stage afloat assembly was applied using a dry caisson. It consists in the fact that on the stocks in manufacture of each section of $126 \times$ $\times 31.5 \times 24.2 \mathrm{~m}$ a half of dry caisson is mounted in its lower part, which is removed later. At the territory of CIS this technology was not used till recently. The joining of two halves of a dry caisson was performed under water at the depth of $8 \mathrm{~m}$ using the technology of mechanized wet welding with self-shielding flux-cored wire. The work is characterized by welding in overhead (126 m per section) and vertical (16 m per section) positions. Under supervision of the Russian Maritime Register of Shipping, not taking into account the interruptions for fitting-out of elements of the platform, $1800 \mathrm{~m}$ of one-pass weld was made in overhead and vertical positions at the depth of $8 \mathrm{~m}$ during 55 working days, taking into account the preparatory-final time. To per- 
Table 2. Basic works performed at restoration of underwater pipeline passages across water barriers

\begin{tabular}{|c|c|c|}
\hline Location of work performance & Type of damage & Technology of repair \\
\hline $\begin{array}{l}\text { The Dnieper river, } 10 \mathrm{~m} \text { depth. Water } \\
\text { conduit, } \varnothing 1020 \times 12 \mathrm{~mm} \text {, steel 09G2 } \\
\text { (1969) }\end{array}$ & $\begin{array}{l}\text { Two cracks: } 1-L \approx 1.5 \mathrm{~m} \text { with } \\
\text { opening in the upper part of a pipe } \\
\text { up to } 30 \mathrm{~mm}, 2-L \approx 250 \mathrm{~mm} \\
\text { along the weld }\end{array}$ & $\begin{array}{l}\text { Technological backings and additional inserts are } \\
\text { introduced inside the repaired area of pipe. They } \\
\text { were joined with pipe by multilayer butt welds }\end{array}$ \\
\hline $\begin{array}{l}\text { The Beysug river, } 5 \mathrm{~mm} \text { depth. Oil } \\
\text { pipeline, } \varnothing 1020 \mathrm{~mm} \text {, steel } 14 \mathrm{KhGS} \\
(1970)\end{array}$ & $\begin{array}{l}\text { Crack along the site butt, due to } \\
\text { lack of penetration in weld root }\end{array}$ & $\begin{array}{l}\text { Mechanical grooving with fixation of crack ends } \\
\text { by drilling. Groove is filled by multilayer butt } \\
\text { weld }\end{array}$ \\
\hline $\begin{array}{l}\text { The Volga river, } 12 \mathrm{~m} \text { depth }(\mathrm{Vol}- \\
\text { gograd city region). Two pipes of } \\
\text { water conduit, } \varnothing 1020 \times 12 \text {, steel } \\
\text { VSt3sp. The repair was performed } \\
\text { within } 2 \text { months }(1971)\end{array}$ & $\begin{array}{l}9 \text { areas with cracks of } L \leq 2500 \mathrm{~mm} \\
\text { and ruptures of } L \leq 1500 \mathrm{~mm} \text { with } \\
\text { opening of up to } 200 \mathrm{~mm}\end{array}$ & $\begin{array}{l}\text { After mechanical grooving the inserts were } \\
\text { introduced to windows and then joined to pipe by } \\
\text { multipass butt welds of } L \approx 38 \mathrm{~m} \text {. Most of welds } \\
\text { were located in vertical and overhead positions }\end{array}$ \\
\hline $\begin{array}{l}\text { The Kazanka river, } 6 \mathrm{~m} \text { depth } \\
\text { (Kazan). Water conduit, Ø820 mm, } \\
\text { steel VSt3sp (1972) }\end{array}$ & $\begin{array}{l}\text { Partial rupture of pipe, which } \\
\text { occurred as a result of violation of } \\
\text { laying out technology }\end{array}$ & $\begin{array}{l}\text { After mechanical grooving a patch was mounted to } \\
\text { the formed window and then joined to pipe by } \\
\text { multilayer butt weld }\end{array}$ \\
\hline $\begin{array}{l}\text { The Dnieper river, } 6 \mathrm{~m} \text { depth (Kher- } \\
\text { son city region). Water conduit, } \\
\varnothing 720 \mathrm{~mm} \text {, steel VSt3sp (1973) }\end{array}$ & $\begin{array}{l}\text { Rupture along the site weld in } 1 / 2 \\
\text { diameter }\end{array}$ & $\begin{array}{l}\text { Mounting of two half-couplings with special inner } \\
\text { grooving at the defective area. Half-couplings were } \\
\text { joined to pipe by fillet multipass welds }\end{array}$ \\
\hline $\begin{array}{l}\text { The Moskva river, } 8 \mathrm{~m} \text { depth. Gas } \\
\text { pipeline passage, } \varnothing 720 \mathrm{~mm} \text {, steel } \\
\text { 09G2 (1974) }\end{array}$ & $\begin{array}{l}\text { Under the effect of dynamic loads a } \\
\text { crack in HAZ metal of site butt was } \\
\text { formed }\end{array}$ & $\begin{array}{l}\text { After mechanical grooving and fixation of ends of } \\
\text { crack by drilling, the formed groove was filled by } \\
\text { multipass butt weld }\end{array}$ \\
\hline $\begin{array}{l}\text { The Ukhta river, } 10 \mathrm{~m} \text { depth. Gas } \\
\text { pipeline passage, } \varnothing 820 \mathrm{~mm} \text {, steel } \\
\text { 14KhGS (1975) }\end{array}$ & $\begin{array}{l}\text { Crack as a result of lack of } \\
\text { penetration in root of site butt }\end{array}$ & Same \\
\hline $\begin{array}{l}\text { The Ob river, } 6 \mathrm{~m} \text { depth (region of } \\
\text { Peregrebnoye village). Gas pipeline } \\
\text { passage } \varnothing 1020 \mathrm{~mm} \text {, steel 09G2 (1976) }\end{array}$ & $\begin{array}{l}\text { Crack formed during service due to } \\
\text { lack of penetration in site butt }\end{array}$ & $\gg$ \\
\hline $\begin{array}{l}\text { The Donuzlav lake (Crimea). Depth } \\
\text { of } 4 \mathrm{~m} \text { at zero visibility. Gas pipeline } \\
\text { passage, } \varnothing 720 \mathrm{~mm} \text {, steel 09G2 (1977) }\end{array}$ & $\begin{array}{l}\text { Cleavages formed as a result of } \\
\text { corrosion damage }\end{array}$ & $\begin{array}{l}\text { Mechanic grooving of defective areas. Welding by } \\
1.4 \mathrm{~mm} \text { diameter wire, as the thickness of metal in } \\
\text { the welding zone did not exceed } 4 \mathrm{~mm}\end{array}$ \\
\hline $\begin{array}{l}\text { The Daugava river, } 18 \mathrm{~m} \text { depth (re- } \\
\text { gion of Riga). Water conduit of } \\
\varnothing 720 \mathrm{~mm} \text {, steel 09G2 (1978) }\end{array}$ & Complete rupture of pipe & $\begin{array}{l}\text { Defective area of pipe was removed by electro- } \\
\text { oxygen cutting. An insert of } 0.5 \mathrm{~mm} \text { length with a } \\
\text { gap, not exceeding } 10 \mathrm{~mm} \text {, was mounted after } \\
\text { mechanical treatment inside the pipe. The insert } \\
\text { was joined to pipe using fillet multipass welds }\end{array}$ \\
\hline $\begin{array}{l}\text { The Ob river, } 7 \mathrm{~m} \text { depth. Passage of } \\
\text { oil pipeline Aleksandrovskoye-An- } \\
\text { zhero-Sudzhensk by pipe of } \varnothing 1020 \times \\
\times 18 \mathrm{~mm} \text {, steel 18G2SAF }(1980-1981)\end{array}$ & $\begin{array}{l}\text { Lack of penetration in root of two } \\
\text { site butts. Cracks in laying out of } \\
\text { siphon }\end{array}$ & $\begin{array}{l}\text { Defective areas of pipe with cracks were removed. } \\
\text { After mechanical treatment of formed edges the } \\
\text { patches with backing elements were mounted to } \\
\text { the pipe using a screw-jack. Due to high carbon } \\
\text { equivalent of steel the repair was made using a } \\
\text { combined method. The first } 3 \text { passes were produced } \\
\text { by wet method using special self-shielding flux- } \\
\text { cored wire. The further filling of groove was } \\
\text { performed using manual welding with covered } \\
\text { electrodes in the caisson with preliminary heating } \\
\text { of pipe }\end{array}$ \\
\hline $\begin{array}{l}\text { The Volga river, } 5 \mathrm{~m} \text { depth (Kazan re- } \\
\text { gion). Two joining couplings at the } \\
\text { city water intake of } \varnothing 1420 \mathrm{~mm} \text {. The } \\
\text { work was performed within } 30 \text { days } \\
\text { (1982) }\end{array}$ & $\begin{array}{l}\text { Gaps between the pipe and joining } \\
\text { half-couplings around perimeter of } \\
\text { pipe reaching } 160 \mathrm{~mm}\end{array}$ & $\begin{array}{l}\text { At the distance of } 3 \mathrm{~m} \text { from the repaired couplings } \\
\text { the operation hatches were cut out, through which } \\
\text { a diver entered inside the pipe and semi automatic } \\
\text { machine was delivered. Pipes to half-couplings } \\
\text { were joined using multipass fillet welds of } 8- \\
20 \mathrm{~mm} \text { leg. The total length of welds was } 28 \mathrm{~m} \text {. To } \\
\text { liquidate large gaps, the covering elements were } \\
\text { applied }\end{array}$ \\
\hline $\begin{array}{l}\text { The Ob river, } 12 \mathrm{~m} \text { depth (region of } \\
\text { Nefteyugansk town). Passage of the } \\
\text { product conduit by pipe of } \varnothing 820 \mathrm{~mm} \text {, } \\
\text { steel 17G1S (1982) }\end{array}$ & Fracture of site butt at $1 / 3$ of length & $\begin{array}{l}\text { The defective area was removed using electro- } \\
\text { oxygen cutting. After mechanical treatment the } \\
\text { insert with backing elements was mounted into the } \\
\text { formed cavity and joined to pipe around perimeter } \\
\text { by multipass butt weld }\end{array}$ \\
\hline
\end{tabular}


Table 2 (cont.)

\begin{tabular}{||l|l|l||}
\hline \multicolumn{1}{|c|}{ Location of work performance } & \multicolumn{1}{|c|}{ Type of damage } & \multicolumn{1}{|c|}{ Technology of repair } \\
\hline $\begin{array}{l}\text { The Dnieper river, 12 m depth (region of } \\
\text { Kremenchug city). Passage of gas pipeline } \\
\text { Yelets-Kremenchug-Krivoj Rog. Pipe of } \\
\varnothing 1420 \times 18.7 \mathrm{~mm} \text {, steel of type X70 } \\
(1987)\end{array}$ & Cleavage in site butt & $\begin{array}{l}\text { After mechanical grooving with } 90^{\circ} \text { angle } \\
\text { of edges opening for the depth of } 16 \mathrm{~mm} \\
\text { the produced groove was filled by } \\
\text { multipass butt weld. Flux-cored wire } \\
\text { was used providing austenite structure of } \\
\text { weld metal }\end{array}$ \\
\hline $\begin{array}{l}\text { The Kama river, } 12 \mathrm{~m} \text { depth (region of } \\
\text { Perm city). Passage of gas pipeline by the } \\
\text { pipe of steel 17G1S (1990) }\end{array}$ & Crack of site butt of $100 \mathrm{~mm}$ length & \multicolumn{1}{|c|}{ Same } \\
\hline
\end{tabular}

form the works the semi-automatic machines A1660 and PSP-3 [3] for underwater welding and flux-cored wire PPS-EK1 [7-9] were used.

Two repairs of underwater gas pipeline passages (see Table 2) were performed using fluxcored wires providing austenite structure of weld metal, and under the full-scale conditions (Chernomorskoe town) at the depth of $10 \mathrm{~m}$ the pipe specimen was rewelded by position welding using the same wire, which withstood the test pressure of $20 \mathrm{MPa}$ [3].

Currently a great volume of works using the technology of mechanized wet welding is performed in Russia at repair of berth erections. The semi-automatic machines for underwater welding A1450 and A1660, produced in the 1980s, and flux-cored wire PPS-EK1 are used. Thus, only the company «Baltijsky Proekt» uses about $900 \mathrm{~kg}$ of wire per year to produce mechanized underwater welding, which is quite comparable with that amount of flux-cored wire produced at the PWI for Navy of USSR and for civil purposes.
To realize the technology of mechanized wet welding and also welding using covered electrodes the sets of equipment were designed as well as technological documentation and methods of training for divers-welders were worked out.

Cutting of metal under water. Cutting of metal structures under water is a quite significant element of technological process in performance of underwater technical works. The technology of cutting under water using exothermal electrodes, produced by the leading word manufacturers, is the most challenging today [3]. Unfortunately, it should be noted that such technologies as cutting under water using flux-cored wire and explosion cutting, developed at the PWI, nowadays are practically not demanded. The electrodes for exothermal underwater cutting, designed at the PWI, the production of which was organized in Russia, do not enter the market at the present time.

Some number of electrodes of the grade ANRT8 and other of $8 \mathrm{~mm}$ diameter for electro-oxygen underwater cutting, manufactured under the

Table 3. Characteristic examples of restoration of berth erections and oil extracting platforms

\begin{tabular}{|c|c|}
\hline Region & Technology of works performance \\
\hline \multicolumn{2}{|r|}{ Repair of berth erections } \\
\hline $\begin{array}{l}\text { Port Dudinka. Violation of integrity of a sheet- } \\
\text { pile wall. Locks between the sheets and piles were } \\
\text { separated (1982-1987) }\end{array}$ & $\begin{array}{l}\text { Repair was made in winter after interruption of navigation. Using fillet welds } \\
\text { of } 6-10 \mathrm{~mm} \text { leg the doubling sheets of } 6-8 \mathrm{~mm} \text { thickness were welded on. } \\
\text { Depth of works fulfillment was from } 1 \text { up to } 14 \mathrm{~m} \text {. More than } 5 \mathrm{~km} \text { of berth } \\
\text { wall was repaired }\end{array}$ \\
\hline Klaypeda port. Sheet-pile berth wall (1982-1983) & $\begin{array}{l}\text { Technology was the same. Depth was } 2-12 \mathrm{~m} \text {, length of fillet welds with } 6^{-} \\
8 \mathrm{~mm} \text { leg was } 287 \mathrm{~m}\end{array}$ \\
\hline $\begin{array}{l}\text { St.-Petersburg sea port. AP BASU «Baltijskie Buk- } \\
\text { siry» (1996) }\end{array}$ & $\begin{array}{l}\text { Technology was the same. Depth of } 2-12 \mathrm{~m} \text {, total length of fillet welds with } \\
8-10 \mathrm{~mm} \text { leg was } 360 \mathrm{~m}\end{array}$ \\
\hline \multicolumn{2}{|c|}{ Repair of stationary oil extracting platforms } \\
\hline $\begin{array}{l}\text { Deep water platform } 12 \text { at the } 26 \text { Baku Commis- } \\
\text { sars sea oil deposit at the Caspian Sea (1991) }\end{array}$ & $\begin{array}{l}\text { Restoration of load-carrying capacity of tubular element of vertical support of } \\
820 \times 10 \mathrm{~mm} \text { of steel } 17 \mathrm{GS} \text {. The support was completely cramped at the depth } \\
\text { of } 4 \mathrm{~m} \text {. The defective area was removed. New area of vertical support was } \\
\text { joined to platform by butt welds }\end{array}$ \\
\hline $\begin{array}{l}\text { Reconstruction of underwater part of support unit } \\
\text { of multipurpose underwater station LAM-22 (2000) }\end{array}$ & $\begin{array}{l}\text { Arrangement of underwater structures with the anodes PAKM-75. Within } 12 \\
\text { days } 115 \text { anodes were assembled and welded at the depth of } 20 \mathrm{~m} \text {. The total } \\
\text { length of welds, made at all spatial positions, was } 55.2 \mathrm{~m} \text {. The performance of } \\
\text { works was supervised by the representative of Lloyd, Germany }\end{array}$ \\
\hline
\end{tabular}


laboratory conditions, reaches the consumer. The quality of these electrodes is sufficiently high, which is confirmed by their regular use at the territory of Russia and Ukraine.

Tendencies of progress. In our opinion, the technology of welding in a dry chamber, containing both welder and also welding unit, will be also further used for assembly and repair of critical hydrotechnical constructions, such as highpressure pipelines and separate elements of stationary platforms under water and also in case of low transparency of water.

We assume the increase in volumes of repair works using new covered electrodes with improved welding and technological properties. At negligible volumes of welding works the application of electrodes is preferable in case of obtaining the strength values adequate to the mechanized method.

The mentioned consumables allow making the conclusion about high efficiency of technology of mechanized wet welding using self-shielding flux-cored wires. The quality of works depends greatly on the level of specialist training. Technological solutions developed and tested in practice allow quick and efficient repair of ship hulls and other hydrotechnical objects at minimum labor costs.

\section{Conclusions}

1. Technology of mechanized wet welding under water using self-shielding flux-cored wire was successfully applied for repair of underwater pipeline passages across the water barriers at the end of the last century.
2. At the present time the repair of underwater pipeline passages using technology of welding under hyperbaric conditions is the most challenging, taking into account a considerable level of wear both from the position of corrosion damage as well as from the position of long effect of dynamic loads.

3. The application of welding technology inside the caisson at atmospheric pressure for repair of underwater pipeline passages is little promising.

4. For underwater cutting the electrodes for exothermal cutting are the most challenging.

1. Paton, B.E., Savich, I.M. (1987) To the 100th anniversary of underwater welding. Avtomatich. Svarka, 12, $1-2$.

2. Evans, N.H. (1974) Welding in offshore constructions. Metal Constr. and British Welding J., 5, $153-157$.

3. Kononenko, V.Ya. (2011) Underwater welding and cutting. Kiev: Ukraina.

4. Kononenko, V.Ya. (2010) Application of method of dry underwater welding in repair of underwater passages of gas and oil pipelines in Russia. The Paton Welding J., 5, 42-46.

5. Savich, I.M. (1969) Flux-cored wire underwater welding. Avtomatich. Svarka, 10, 70.

6. Kononenko, V.Ya. (2004) Technology of underwater welding and cutting. Kiev: Ekotekhnologiya.

7. Kononenko, V.Ya. (2005) Technology of wet mechanized welding in construction of IRSSP «Prirazlomnaya». The Paton Welding J., 9, 33-35.

8. Kononenko, V.Ya. (2006) Technologies of underwater wet welding and cutting. Kiev, PWI.

9. Kononenko, V.Ya. (2005) Application of the technology of mechanized underwater welding in construction of OIRSP «Prirazlomnaya». The Paton Welding $J ., 12,47$.

Received 22.04.2014 